\title{
Tomato Yellow Leaf Curl Virus: A Whitefly-Transmitted Geminivirus with a Single Genomic Component
}

\author{
NIR NAVOT, ${ }^{2}$ ERAN PICHERSKY, ${ }^{*}$ MUHAMMAD ZEIDAN, DANI ZAMIR, AND HENRYK CZOSNEK² \\ Department of Field and Vegetable Crops and the Otto Warburg Center for Biotechnology in Agriculture, Faculty of Agriculture, \\ The Hebrew University of Jerusalem, P. O. Box 12, Rehovot, 76100 Israel; and *Biology Department, \\ Natural Science Building. The University of Michigan, Ann Arbor, Michigan 48109
}

Received February 26, 1991; accepted July 2, 1991

\begin{abstract}
The genome of the tomato yellow leaf curl virus (TYLCV), a Bemisia tabaci-transmitted geminivirus, was cloned. All clones obtained were of one genomic molecule, analogous to DNA A of African cassava mosaic virus. Nucleotide sequence analysis of the TYLCV genome showed that it comprises 2787 nucleotides, encoding six open reading frames, two on the virion strand and four on the complementary strand. All of them have counterparts in other geminiviruses. Dimeric copies of the cloned viral genome were introduced into tomato plants by agroinoculation. Severe yellow leaf curl disease symptoms developed in all of them. Effective whitefly-mediated tranemission of the virus from agroinoculated plants to test plants demonstrated that the cloned molecule carries all the information needed for virus replication, systemic infection, and transfer by whiteflies. Restriction and hybridization analyses of viral DNA forms in infected plants and viruliferous whiteflies did not support the presupposed existence of a second genomic component. This is the first report of a whitefly-transmitted geminivirus that possesses a single genomic molecule. 1991 Academic Press, Inc.
\end{abstract}

\section{INTRODUCTION}

Tomato yellow leaf curl virus (TYLCV) is a whiteflytransmitted geminivirus that causes severe damage to tomato crops in the Middle East (Cohen and Harpaz, 1964; Czosnek et al., 1988a). Symptoms similar to those produced by this disease have also been described in North and Central Africa, South East Asia, and Taiwan (Makkouk and Laterrot, 1983; Czosnek et al., 1990).

Geminiviruses are characterized by a covalently closed circular single-stranded DNA genome (cssDNA) encapsidated in geminate particles (Goodman, 1977). They have been usually classified into two major subgroups, based on their insect vector, host range, and genome organization (reviewed by Lazarowitz, 1987; Davies and Stanley, 1989). One subgroup included leafhopper-transmitted viruses that infect mainly monocotyledonous plants and possess a single genomic component. The other subgroup included viruses that are transmitted by the whitefly Bemisia tabaci, infect dicotyledonous plants, and possess a bipartite genome. In infected plants, the two viral genomic components (designated as DNA A and DNA B) were found to be equally represented both in the viral

\footnotetext{
' Current address: Department of Cell Biology, The Weizmann Institute of Science, Rehovot, 76100 Israel.

${ }^{2}$ To whom requests for reprints should be addressed.
}

genomic single-stranded DNA (ssDNA) and in its double-stranded DNA (dsDNA) replicative form (RF) (lkegami et al., 1981; Hamilton et al., 1982; Stanley and Townsend, 1985; Abouzid et al., 1988; Lazarowitz and Lazdins, 1991). While DNA A can replicate autonomously, DNA $B$ depends on the presence of $A$ to replicate (Rogers et al., 1986; Elmer et al., 1988). DNA B is necessary for systemic spread of the virus (Elmer et al., 1988; Etessami et al., 1988). Disease symptoms appear in plants only when both viral genomic components are present simultaneously (Stantey, 1983). Recently, Rochester and co-workers (1990) described the cloning of a TYLCV-like whitefly-transmitted geminivirus with a bipartite genome from Thailand. The $A$ component of this virus can cause systemic infection in plants following agroinoculation, in the absence of the $\mathrm{B}$ component. The disease symptoms presented by these plants are less pronounced than those produced in plants agroinoculated with both components.

Since a bipartite genome seemed to be a unifying feature of whitefly-transmitted geminiviruses, it was assumed that TYLCV would possess two genomic components too. Yet we show here that only a single viral genomic component could be found in TYLCV-infected plants and viruliferous whiteflies. We describe the cloning and sequencing of this molecule and demonstrate its infectivity in tomato, by means of agroinoculation and whitefly-mediated plant-to-plant transmission. 


\section{MATERIALS AND METHODS}

\section{Sources of virus}

TYLCV-infected tomato plants (Lycopersicon esculentum Mill.) from several field locations in Israel and both jimsonweed (Datura stramonium L.) and tomato plants from an insect-proof greenhouse in the Agriculture Research Organization at Bet Dagan served as sources for viral DNAs. The latter harbor the original TYLCV isolate described by Cohen and Harpaz (1964) and used by Czosnek et al. (1988a) for the isolation and characterization of TYLCV.

\section{Materials and bacterial strains}

Enzymes were from Boehringer-Mannheim, United States Biochemical Corp. (USB), and New England Biolabs. The 1-kb ladder DNA size marker was from USB. Synthetic oligonucleotides were from Biotechnology General (Rehovot, Israel). GeneScreen Plus hybridization membranes and radiolabeled nucleotides were from New England Nuclear (NEN). The pTZ18 plasmid was from Pharmacia. Escherichia coli strains XL-1 blue $[R e c A]$ and NM522 and the pBluescript SK+ vector were from Stratagene. The pCGN1547 binary vector and Agrobacterium tumefaciens LBA4404 (Hoekema et al., 1983) were kindly provided by Calgene (Davis, CA). The pBIN 19 binary vector (Bevan, 1984) was from Clonetech Laboratories (Palo Alto, CA).

\section{DNA extraction, electrophoresis, and hybridization}

Crude DNA extracts (lysates) from leaves and roots were prepared as described previously (Czosnek et al., 1988b). Total leaf DNA was extracted according to Taylor and Powell (1982). Extracts of nucleic acids from infected plants could be greatly enriched in TYLCV dsDNA by quick precipitation of DNA from lysate upon the addition of 0.6 vols of isopropanol. Lysates and DNA samples were subjected to electrophoresis in $1.5 \%$ agarose gels, either with ethidium bromide (lysates) or without it (purified DNA), depurinated in $0.25 \mathrm{~N} \mathrm{HCl}$ for $15 \mathrm{~min}$, and transferred onto membranes in $1.5 \mathrm{M} \mathrm{NaCl}$ and $0.5 \mathrm{~N} \mathrm{NaOH}$. Probes were radiolabeled by nick-translation (Rigby et al., 1977) and by random priming with hexanucleotides (Feinberg and Vogelstein, 1984). Hybridizations were done either at $67^{\circ}$ (stringent conditions) or at $42^{\circ}$ (nonstringent conditions) as described by Sambrook et al. (1989). Blots were washed in $1 \times$ SSC- $0.1 \%$ SDS for $2 \times 30 \mathrm{~min}$, either at $60^{\circ}$ (high stringency) or at $42^{\circ}$ (low stringency). TYLCV DNA forms in infected plants were identified as described previously (Czosnek et al., 1989) and their identification was confirmed with TYLCV strand-specific ssDNA probes (Zilberstein et al., 1989). Rapid detection of TYLCV nucleic acids in plants was achieved by hybridizing leaves squashed on membranes (squash-blot) (Navot et al., 1989).

\section{Isolation and cloning of TYLCV dsDNA}

DNA was extracted from TYLCV-infected plants and subjected to agarose gel electrophoresis. The supercoiled covalently closed circular DNA form of TYLCV $\mathrm{RF}$ (cccDNA) was isolated from the gel as described previously (Czosnek et al., 1989), digested by Hpall, and cloned into the Accl site of the pTZ18 plasmid. TYLCV dsDNA was also cloned after DNA extracts from infected plant were digested by ECoRI, Sacl, or Pstl. Linearized viral dsDNA was size selected using either agarose gels or sucrose gradients, purified, and ligated with appropriately digested pTZ18. Ligation mixtures were used to transform $E$. coli NM522. Clones containing TYLCV DNA were identified by hybridization of colony blots with radiolabeled virion DNA (Czosnek et al., 1988b) and subjected to restriction analysis.

\section{DNA sequence analysis}

Sequencing was performed by the chemical degradation procedure (Maxam and Gilbert, 1980) and by the chain termination method (Sanger et al., 1977). The data were compiled and analyzed using the GCG sequence analysis package (Devereux et al., 1984) and the DNA Strider application for the Macintosh (Marck, 1988). The sequence of cloned TYLCV DNA was compared to the published sequences of 10 geminiviruses using the BigGap function of the GCG package.

\section{Infectivity of cloned TYLCV DNA}

For infectivity assays in tomato, we constructed tandem direct repeats (dimers) of two TYLCV clones and inserted them into the pCGN1547 and pBIN 19 vectors (see Results). These were introduced into $A$. tumefaciens LBA4404 by direct transformation (An et al., 1988). For agroinoculation experiments (Grimsley et al., 1987), a 200-ml culture of LBA4404 was grown at $28^{\circ}$ for $48 \mathrm{hr}$, subjected to centrifugation, and resuspended in $10 \mathrm{ml}$ of sterile water. The bacteria were injected into plant crowns, stems, and bases of shoot nodes. Twenty-eight tomato plants ( $L$. esculentum $\mathrm{cv}$. Monique) and eight plants of a tomato interspecific $F 1$ hybrid (L. esculentum CV. M82 $\times$ L. pennellii LA716) at their four-leaf stage were agroinoculated. Plants were kept at $25^{\circ}$ in a limited-access insect-free growth chamber, with 1800-lux illumination for $16 \mathrm{hr} /$ day.

\section{Plant-to-plant whitefly-mediated transmission of TYLCV}

The whitefly colony was maintained on TYLCV-free cotton plants (Gossypium hirsutum L.) in insect-proof 
cages at $30^{\circ}$ with a 16 -hr/day illumination regime (Zeidan and Czosnek, 1991). To transmit the TYLCV disease from agroinoculated to uninfected tomato plants, about 60 whiteflies had access to each agroinoculated plant for an acquisition period of $24 \mathrm{hr}$; each plant was kept in a separate insect-proof cage. Then, the insects collected from each plant were placed on four uninfected tomato plants at their four-leaf stage; each group of four plants was kept in a separate cage.

\section{Analysis of TYLCV ssDNA in whiteflies}

DNA was extracted from whiteflies following a 24-hr access period to TYLCV-infected tomato plants. The insects were ground in $0.5 \%$ SDS $-100 \mu \mathrm{g} / \mathrm{ml}$ proteinase $K$ and the mixture was incubated for $2 \mathrm{hr}$ at $55^{\circ}$. Nucleic acids isolated by phenol-chloroform extractions were ethanol-precipitated and dissolved in TE $(\mathrm{pH}$ 8.0) (Czosnek et al., 1989; Zeidan and Czosnek, 1991). To make possible the cleavage of TYLCV ssDNA present in whiteflies, it was rendered partially doublestranded. Complementary oligomers were annealed with the SSDNA in a nucleic acid extract from 200 viruliferous whiteflies, as the mixture was heated to $75^{\circ}$ and slowly cooled to $45^{\circ}$. The partially doublestranded DNA was incubated for $2 \mathrm{hr}$ with restriction endonucleases, subjected to electrophoresis, and transferred to a membrane.

\section{RESULTS}

\section{Cloning of the single TYLCV genomic molecule}

Our cloning strategy was based on two characteristics of whitefly-transmitted geminiviruses: (1) Their two genomic components, DNA A and DNA B, are present in roughly equimolar amounts in infected plants. (2) DNA A and DNA $B$ of each virus show little homology, except for a region of $\sim 200$ nucleotides (the "common region"- $-\mathrm{CR}$ ). The $\mathrm{CR}$ is highly conserved in the two genomic components of each virus, but the CRs of the different geminiviruses are unrelated. Within this region resides a conserved inverted repeat that always contains a single Hpall site (Lazarowitz, 1987). Thus, Hpall could be used to clone both genomic components in a single cloning event.

The supercoiled dsDNA form of the TYLCV RF isolated from field-infected tomato plants was linearized with Hpall and cloned into an Accl-restricted pTZ18. Colonies containing TYLCV DNA were identified by hybridization with virion SSDNA. Restriction analysis indicated that of the 19 clones obtained, 18 contained inserts of $\sim 2.8 \mathrm{kbp}$ and were very closely related (the Hpall clones were designated pTYH1 to 9 and 11 to 20). One clone (pTYH4) had an insert of $\sim 0.3 \mathrm{kbp}$. Its existence reflected an otherwise undetected polymor-

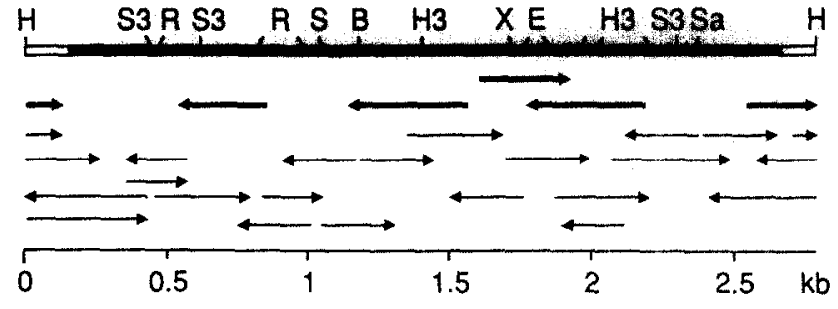

FIG. 1. DNA sequencing strategy of the cloned TYLCV genome. The genome is represented as a thick black line, with the intergenic region not shaded. Sites of restriction endonucleases used for subcloning are shown: $B C /(B)$; EcoRI (E); Haell (H3); Hpall (H), Rsal (R); Sacl (Sa); Sau3Al (S3); Sphl (S), and Xbal (X). Arrows below the map indicate the direction and extent of sequencing. Thick arrows are sequences obtained by the dideoxy chain termination method, with the aid of synthetic primers. Thin arrows are sequences obtained by subjecting subclones to the chemical degradation procedure

phism in the pool of TYLCV RF molecules. The second Hpall site that gave rise to the $0.3-\mathrm{kbp}$ fragment was shown by sequence analysis to have originated from a single base change at nucleotide 488 (Fig. 2).

TYLCV dsDNA was also cloned in other restriction sites. Six ECORI clones (designated pTYE1 to 6) were obtained from individual field-infected tomato plants. Two Sacl clones (designated PTYS1 and 2) were obtained from a greenhouse isolate of TYLCV maintained in tomato and in jimsonweed; 15 Pstl clones (designated pTYP1 to 15) unique for that isolate were also obtained from these plants.

Clones were subjected to restriction analysis. Representative clones were hybridized with radiolabeled probes from African cassava mosaic virus (ACMV) DNA A and B. All of them hybridized with ACMV DNA A but not with DNA B (not shown).

\section{Sequence analysis of the TYLCV genome}

Two independent Hpall clones (pTYH19 and pTYH20), inserted in opposing orientations into the pTZ18 vector, were used for sequence analysis. Subclones were created by digestion of pTYH19/20 with EcoRI, Sacl, Sphl, and Xbal, followed by self-ligation and thereafter by subcloning of Haell, Sau3AI, and Rsal fragments of the initial subclones into pUC18 (Fig. 1). The nucleotide sequence around the single Hpall site used for cloning was verified by partial sequencing of an ECORI clone ( $\mathrm{PTYE} 1$ ). The resulting sequence of 2787 nucleotides ( $27 \% \mathrm{~A}, 32 \% \mathrm{~T}, 19 \% \mathrm{C}$, and $22 \% \mathrm{G})$ is shown in Fig. 2 in the virion (sense) strand (EMBL GeneBank accession No. X15656). The $5^{\prime}$ end of the intergenic region (IR) was designated as nucleotide 1. Sequence analysis of an EcoRI clone (PTYE1) revealed minor variations between it and the two Hpall clones. Since these clones were obtained in separate cloning 


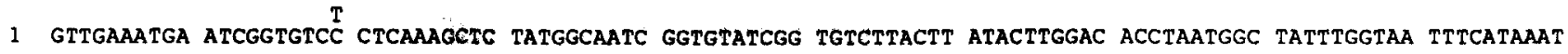

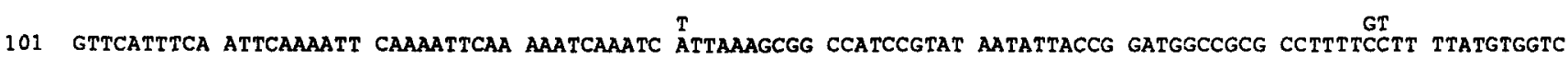
201 CCCACGaggg tTacacagat G C C C

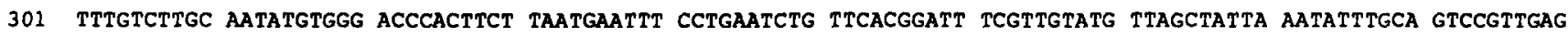

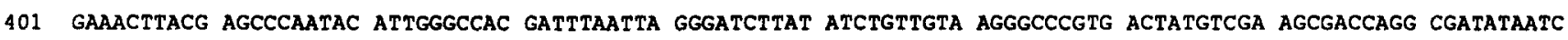
501 ATTTCCACGC CCGTCTCGAA GgTTCGCCGA AGGCTGAACT TCGACAGCCC ATACAGCAGC CGTGCTGCTG TCCCCATTGT CCAAGGCACA AACAAGCGAC

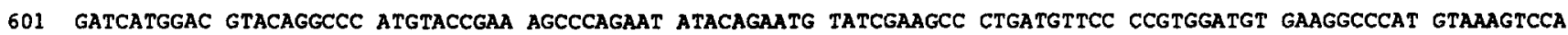

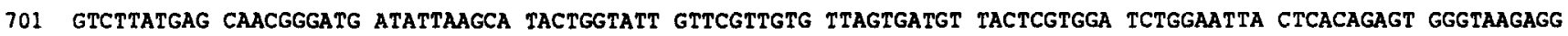

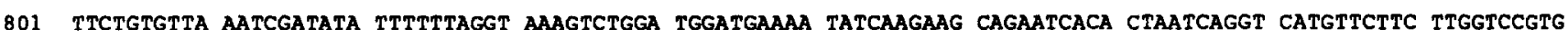

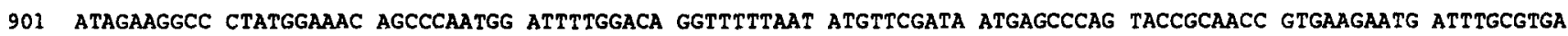

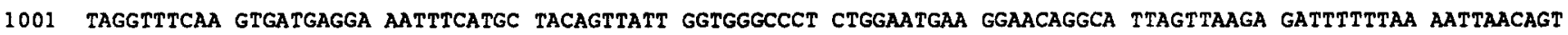

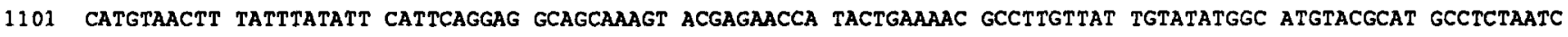

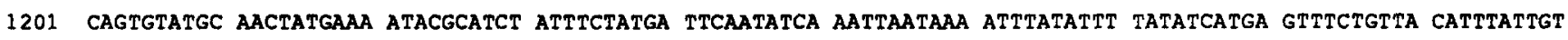

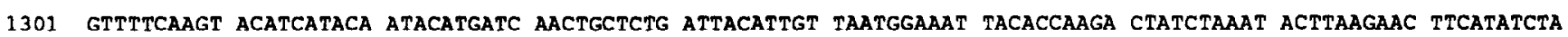
1401 AATACTCTTA AGAAATGACC AGTCTGAGGC TGTAATGTCG TCCAAATTCG GAAGTCGAGA AAACATTTGT GAATCCCCAT TACCTTCCTG ATGTTGTGGT 1501 TGAATCTTAT CTGAATGGAA ATGATGTCGT GGTTCATTAG AAATGGCCTC TGGCTGTGIT CTGTTATCtT GAAATAGAGG GGATTGTTTA TCTCCCAGAT

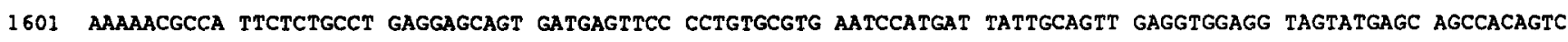
1701 TAGGTCTACA CGCTIACGCC TTATTGGTTT CTTCTTGGCT ATCTTGTGTT GGACCTTGAT TGATACTTGC GAACAGTGGC TCGTAGAGGG TGACGAAGGT

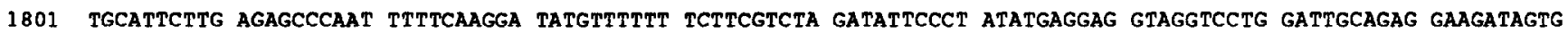
1901 GGAATTCCCC CTTTAATTTG AATGGGCTTC CCGTACTTTG TGTTGCTTTG CCAGTCCCTC TGGGCCCCCA TGAATTCCTT GAAGTGCTT AAATAATGCG

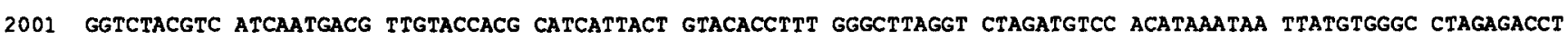
2101 GGCCCACATT GITITGCCTG TICTGCTATC ACCCTCAATG ACAATACTTA TGGGTCTCCA TGGCCGCGCA GCGGAATACA CGACGTTCTC GGCGACCCAC 2201 TCTTCAAGTT CATCTGGAAC TTGATTAAAA GAAGAAGAAA GAAATGGAGA AACATAAACT TCTAAAGGAG GACTAAAAAT CCTATCTAAA ITTGAACTTA

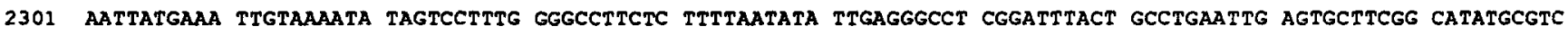
2401 GTTGGCAGAT TGCTGACCTC CTCTAGCTGA TCTGCCATCG ATTTGGAAA CTCCAAAATC AATGAagtTT CCGTCTTTCT CCACGTAGGT CTTGACATCT 2501 GTTGAGCTCT TAGCTGCCTG AATGTTCGGA TGGAATGTG CTGACCTGTT TGGGGATACC AAGTCGAAGA ACCGTTGGTT CTTACATTGG TATTTGCCTT

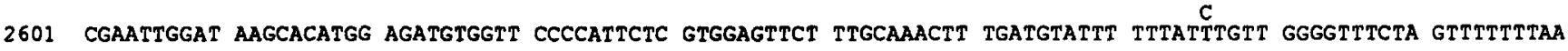

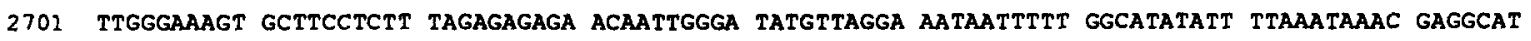

FIG. 2. Nucleotide sequence of the TYLCV genome. The sequence is displayed in the virion DNA sense. The first nucleotide at the 5 ' end of the IR was designated as nucleotide 1. Variable bases, found in clone pTYE1, are shown above the sequence.

experiments, this variation was not unexpected. The variable bases found in PTYE1 are shown above the complete sequence in Fig. 2.

DNA sequence comparisons between TYLCV and
10 geminiviruses with published sequences showed that TYLCV is most closely related to the DNA A genomic component of ACMV (Stanley and Gay, 1983) with $73 \%$ similarity between their aligned sequences. 
TABLE 1

Open ReAding Frames in TYLCV DNA and HOMOLOGIES WITH COUNTERPARTS In Four GEMINIVIRUSES

\begin{tabular}{|c|c|c|c|c|c|c|c|c|c|}
\hline \multirow[b]{2}{*}{ ORF } & \multirow[b]{2}{*}{ Frame } & \multirow[b]{2}{*}{ Start } & \multirow[b]{2}{*}{ Stop } & \multirow{2}{*}{$\begin{array}{l}\text { Amino } \\
\text { acids }\end{array}$} & \multirow{2}{*}{$\begin{array}{l}\text { Protein MW } \\
\text { (daltons) }\end{array}$} & \multicolumn{4}{|c|}{ Amino acid homology } \\
\hline & & & & & & ACMV & TGMV & BCTV & WDV \\
\hline$V_{1}$ & +2 & 474 & 1256 & 260 & 30,300 & $90.7(80.2)$ & $82.6(74.1)$ & $48.7(23.1)$ & $41.5(18.2)$ \\
\hline$V_{2}$ & +1 & 314 & 664 & 116 & 13,450 & $91.2(72.6)^{b}$ & - & $43.1(17.0)$ & $55.4(25.7)$ \\
\hline $\mathrm{C}_{1}$ & -1 & 2787 & 1714 & 357 & 40,653 & $81.2(71.7)$ & $79.4(69.2)$ & $74.9(61.3)$ & $54.6(34.1)^{\circ}$ \\
\hline $\mathrm{C} 2$ & -2 & 1805 & 1400 & 135 & 15,601 & $77.8(63.7)$ & $69.3(52.0)$ & $51.2(29.6)$ & - \\
\hline $\mathrm{C}_{3}$ & -3 & 1657 & 1255 & 134 & 15,929 & $86.6(73.1)$ & $71.0(56.5)$ & $66.4(40.6)$ & - \\
\hline $\mathrm{C} 4$ & -2 & 2636 & 2343 & 97 & 11,091 & $44.3(34.0)^{\sigma}$ & $58.8(49.4)$ & $60.0(49.4)$ & $\ldots$ \\
\hline
\end{tabular}

${ }^{a}$ Percentage of conserved homology in amino acid sequence is followed in parentheses by the percentage of direct homology. Geminiviruses used for comparisons were: African casava mosaic virus (ACMV; Stanley and Gay, 1983), tomato golden mosaic virus (TGMV; Hamilton et al., 1984), beet curly top virus (BCTV; Stanley et al., 1986), and wheat dwart virus (WDV; MacDowell et al., 1985).

${ }^{\circ}$ The 13.1-kDa ORF in the virion (sense) of ACMV DNA A.

"Compared to the predicted sequence of the spliced mRNA of WDV (Schalk et al., 1989).

${ }^{a}$ Compared to the amino acid sequence of the protein translated from the second AUG in this ORF.

\section{Potential coding regions and regulatory sequences}

To locate potential genes, the DNA sequence was screened on both strands for ORFs with coding potential for proteins of molecular weight $\geqslant 10,000 \mathrm{Da}$. The ORFs, named according to the terminology of Davies and Stanley (1989), are described in Table 1 and their organization along the genome is depicted in Fig. 3.

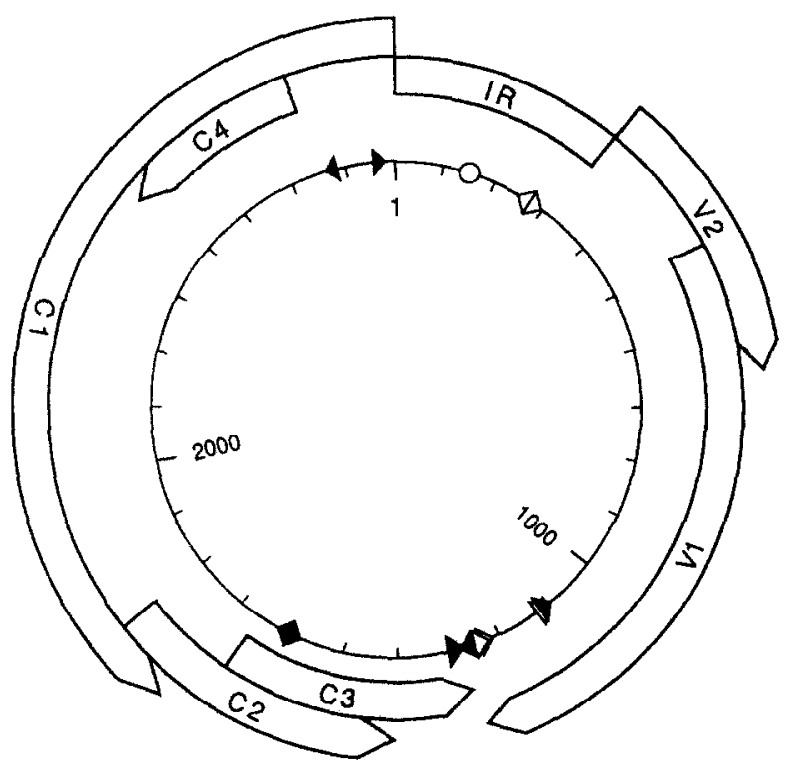

Fig. 3. Potential coding regions in TYLCV DNA. Open reading frames that start with an ATG and have the potential to code for proteins with a molecular weight $\geqslant 10,000 \mathrm{Da}$ are displayed. The name of each ORF is indicated, corresponding to Table 1. Potential TATA boxes are denoted by open triangles. Polyadenylation signals with the sequence G/AATAAA are denoted by solid triangles. The $\mathbb{R}$ and the position of the conserved stem and loop structure (depicted as a small circle) are also shown.
Two ORFs were located in the virion strand. The predicted amino acid sequence of ORF $V_{2}$, which precedes $V 1$ (the coat protein gene), is highly homologous to an ORF of $13.1 \mathrm{kDa}$, which is found in the same location in DNA A of ACMV, but is absent from the genomes of other whitefly-transmitted geminiviruses (Table 1). On the complementary strand, we found three ORFs analogous to the $A C 1, A C 2$, and $A C 3$ ORFs (designated also as AL1, AL2, and AL3) of the whitefly-transmitted geminiviruses (Davies and Stanley, 1989) and a fourth ORF-C4 - that is present in the same region in the genomes of all the geminiviruses that infect dicotyledonous plants. $\mathrm{C} 4$ is seldom shown in the ORF maps of these viruses, possibly because the size of its expected transiation product fails often just below $10 \mathrm{kDa}$.

The sequence element with the potential to form a hairpin structure, found in IRs of all geminiviruses (Lazarowitz, 1987), was located between nucleotides 149 and 177 with the conserved loop sequence TAATATTAC. Potential promoters conforming to the consensus sequence TATAT/AA (Breathnach and Chambon, 1981) were located in positions similar to those of promoters found in ACMV and tomato golden mosaic (TGMV) virus (respectively, Stanley and Gay, 1983; Hamilton et al., 1984) (Fig. 3). The positions of putative polyadenylation signals with the consensus sequence G/AATAAA (Messing et al., 1983) are shown in Fig. 3.

\section{Construction of TYLCV dimers}

Two complete tandem direct repeats of the cloned TYLCV genome (dimers) were constructed for agroinoculation experiments.

One dimer was constructed by combining one Hpall clone (pTYH20) and one EcoRI clone (pTYE1) as out- 
1

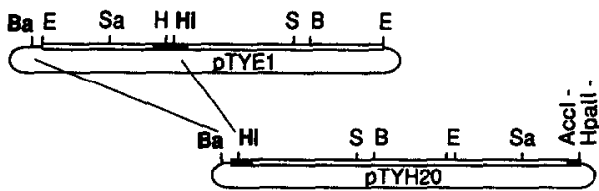

2
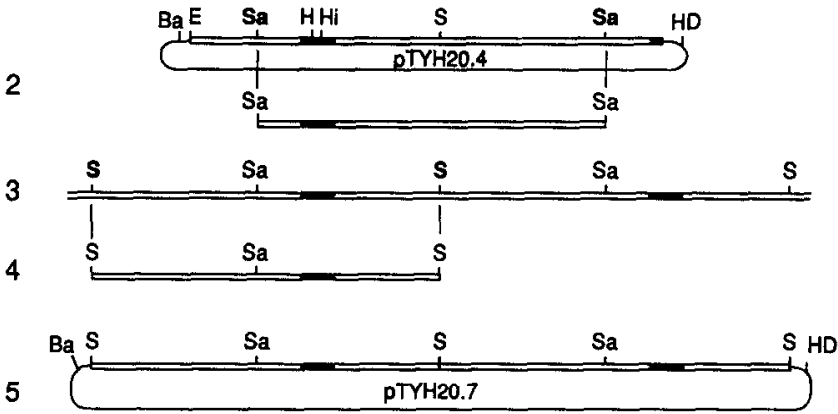

Fig. 4. Construction of TYLCV dimer PTYH20.7. (1) Clones pTYH2O and pTYE1 were digested with BamHI and Hincll. The fragment containing the IR from pTYE1 was inserted into $\mathrm{pTYH} 20$, replacing its small BamHI-Hincll fragment, to produce pTYH20.4. (2) This clone was then cut with Sacl and the 2.8-kbp viral fragment was isolated and self-ligated in a small volume to favor production of multimers. (3) The resulting multimeric DNA was treated with Sphl and separated by electrophoresis in a $1.5 \%$ agarose gel. (4) A 2.8$\mathrm{kbp}$ band was eluted and ligated to $\mathrm{pTZ18}$, in a high insert-to-vector ratio. (5) One clone that contained a complete tandem repeat of the viral genome was identified (pTYH20.7) and its integrity was verified by restriction analysis and partial sequencing. Restriction sites indicated are: BamHI (Ba), EcoRI (E), Sacl (Sa); Hincll (Hi), Hpall (H), Sphl (S), Bcll (B), Hindll (HD).

lined in Fig. 4. This was done because the original Hpall site of pTYH2O was lost as the result of the cloning in the pTZ18 Accl site. The integrity of the resulting cloned dimer (designated PTYH20.7) was verified by restriction analysis and partial sequencing. To determine if pTYH20.7 was functional, it was introduced into tomato protoplasts. Both its replication and the production of viral ssDNA form were observed (not shown). The 5.6-kbp Hindlll-BamHI fragment of $\mathrm{pTYH} 20.7$ which contained the complete TYLCV dimer was ligated into a Hindlll- and BamHI-restricted pBIN19 binary vector to give $\mathrm{pTY} 60$.

To construct the second TYLCV dimer, the 2.8-kbp insert from one Pstl clone (pTYP4) was isolated and ligated with a Pstl-restricted pCGN1547 binary vector, in a high insert-to-vector ratio. Several clones with a tandem direct repeat of the TYLCV genome were identified by restriction analysis. One of these clones, designated pTY4, was used in our experiments.

The dimers in pBIN 19 and pCGN 1547 binary vectors were introduced into $A$. tumefaciens LBA4404. The integrity of the dimers in their Agrobacterium host was verified by restriction and hybridization analyses of total DNA isolated from the transformed bacteria.
The cloned TYLCV genome causes systemic infection in agroinoculated plants

Twelve tomato plants were agroinoculated with pTY60 (containing the Hpall TYLCV dimer) and 24 with pTY4 (containing the Pstl TYLCV dimer). Viral DNA was detected by squash-blotting in 34 of the 36 plants 6 days postinoculation (not shown). Severe yellow leaf curl symptoms that were indistinguishable from those associated with natural whitefly-mediated infection appeared in all the agroinoculated plants about 15 days postinoculation (not shown). At this time, TYLCV ssDNA and dsDNA were detected in crude DNA preparations (lysates) from leaves of all agroinoculated plants (Fig. 5, lane 3). Identical results were obtained with both dimers. Neither viral DNA nor tomato yellow leaf curl disease symptoms were detected in plants inoculated with Agrobacterium containing binary vectors without TYLCV DNA (not shown).

\section{The cloned TYLCV genome is whitefly transmittable}

Whiteflies were used to transmit TYLCV from agroinoculated plants to uninfected tomato test plants. Whiteflies which had access to four plants ( $L$. esculentum) agroinoculated 6 weeks earlier with pTY4 were used to inoculate 16 plants. As inoculation controls, whiteflies which had access to a TYLCV-infected tomato plant from the field were placed on four tomato test plants. Whiteflies from the insect colony kept on

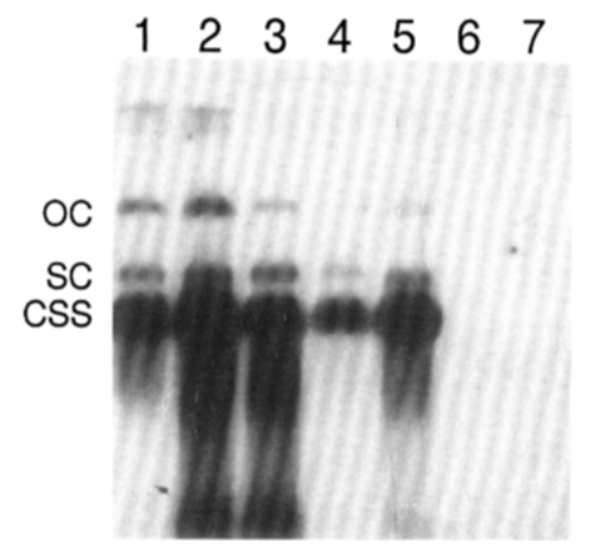

Fig. 5. TYLCV DNA forms in agroinoculated and whitefly-inoculated tomato plants. Crude DNA preparations (lysates) were extracted from roots (lane 1) and leaves (lane 2) of a tomato plant inoculated by whiteflies that had acquired TYLCV from the agroinoculated plant; from leaves of an agroinoculated plant (lane 3); from roots (lane 4) and leaves (lane 5) of a tomato plant inoculated by whiteflies that had acquired the virus from a TYLCV-infected tomato plant from the field; and from roots (lane 6) and leaves (lane 7) of a tomato plant mock-infected with insects fed on cotton plants. The blot was hybridized with a full-length clone of TYLCV. The positions of the open circular (oc) and supercoiled (sc) TYLCV dsDNA and of the circular single-stranded TYLCV DNA (css) are indicated. 
cotton plants were also placed on four tomato test plants.

In 15 of the 16 plants inoculated with whiteflies fed on agroinoculated tomato, TYLCV DNA was detected by squash-blotting after 1 week. Typical disease symptoms appeared in all the plants within 3 weeks postinoculation (not shown). TYLCV ssDNA and dsDNA species were seen in lysates prepared from leaves and roots of these plants 3 weeks postinoculation (Fig. 5, lanes 1, 2). At that time, 3 of the 4 plants inoculated by whiteflies fed on a field-infected plant contained viral DNA (Fig. 5, lanes 4, 5). Neither viral DNA nor symptoms were found in the plants mock-inoculated by whiteflies raised on cotton plants (Fig. 5, lanes 6, 7), confirming that the whitefly colony was TYLCV-free.

\section{The search for the putative TYLCV DNA B component}

Our strategy was based on the observation that except for the $C R$, the sequences of DNAs $A$ and $B$ in geminiviruses with a bipartite genome share almost no homology; thus outside the CR their restriction maps are different. On the basis of this high level of homology between the CRs in DNAs $A$ and $B$, we assumed that the IR of TYLCV (which spans the potential CR) could be used as a probe to detect both putative components. If TYLCV possessed two genomic components, cleavage of the viral dsDNA by restriction endonucleases would produce fragments whose length totalled $5.6 \mathrm{kbp}$. If recognition sites for a certain enzyme existed in only one of the components, fragments that add up to $2.8 \mathrm{kbp}$ and an uncut dsDNA would be seen. A probe containing the CR would detect at least one fragment from each of the components. A probe specific for DNA A would detect either the uncut dsDNA species or some restriction fragments, but not both. If TYLCV had only a single genomic molecule, digesting it with restriction endonucleases would produce fragments that add up to $2.8 \mathrm{kbp}$ and agree with the restriction map derived from the sequence of the cloned component. No uncut viral DNA species should be seen.

The probes generated for the detection of TYLCV DNA A and the putative DNA B are shown in Fig. 6. As a probe capable of detecting both DNA $A$ and $B$, we used the potential common region of TYLCV. This was done by subcloning a 347-bp-long Alul-Alul fragment of the IR from an ECoRI clone of TYLCV (pTYE1) into pBluescript SK+ (pTYE1.2). As DNA A-specific probes, we used a Hinfl-Hinfl fragment of 1146 bp spanning the $\mathrm{C} 1$ and $\mathrm{C} 4$ ORFs of TYLCV subcloned into pBluescript SK+ (pTYH20.23); a 170-bp-long Haelll-Haelll fragment of the $\mathrm{C} 1$ ORF subcloned into pUC18 (pTYH20.15); and a Haelli-EcoRI fragment of $357 \mathrm{bp}$

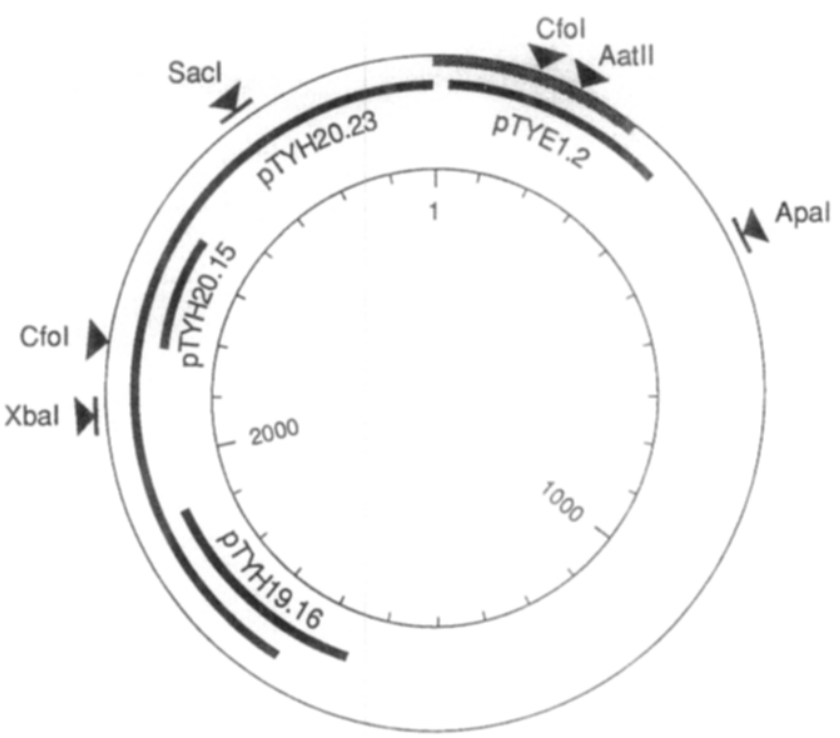

Fig. 6. Location of probes and of complementary oligonucleotides used for restriction and hybridization analyses of TYLCV DNA. The genome is displayed as a circle with the IR as a thick grey region. Probes used for the hybridization analysis are depicted inside the circle as thick black lines. pTYE1.2 (a 347-bp Alut-Alut subclone) was used to detect DNA $A$ as well as the putative DNA $B$. pTYH20.23 (a 1149-bp Hinfl-Hinfl subclone), pTYH20.15 (a 170-bp Haell-Haell subclone), and pTYH19.16 (a 357-bp Haell-EcoRI subclone) were used as DNA A-specific probes. The locations of complementary oligonucleotides used for analysis of ssDNA in whiteflies are shown as short black lines outside the circle. The recognition sites of restriction endonucleases used in restriction and hybridization analyses are indicated by black triangles.

spanning the C2 ORF subcloned into pUC18 (pTYH 19.16). The ACMV DNA A full-length clone pJS092 (Stanley, 1983) was also used as a DNA A-specific probe, because the intergenic regions of ACMV and TYLCV are divergent and do not hybridize with each other under stringent conditions.

\section{The putative TYLCV DNA B was not found in TYLCV dsDNA from infected plants}

Infected tomato leaf DNA enriched in TYLCV dsDNA was analyzed with eight restriction endonucleases for which no recognition sites were found in any of the TYLCV RF-derived clones: BamtHI, ECoRV, HindllI, Konl, Pvul, Sall, Smal, and Xhol; with six restriction endonucleases for which one or two sites were found: $B c l$, Cfol, EcoRl, Hpall, Sacl, and Xbal; and with two endonucleases, Aatll and PSt , for which either one or no sites were found. Hybridization with the DNA Aspecific probes showed that enzymes for which no site exists in the cloned molecule did not cut TYLCV dsDNA. Enzymes for which there are recognition sites in the cloned molecule of TYLCV (as indicated by sequence analysis) either linearized the viral dsDNA or 


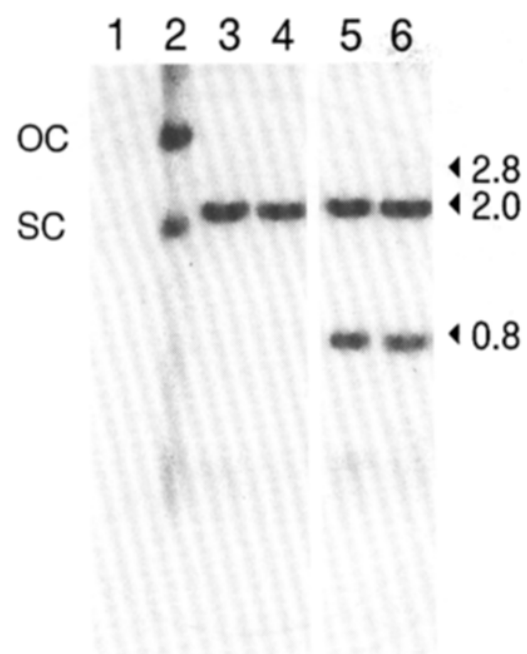

Fig. 7. Restriction and hybridization analysis of TYLCV dsDNA Total nucleic acids were extracted from two infected tomato plants and greatly enriched in TYLCV dsDNA. The DNA from an uninfected tomato plant (lane 1) and that from the infected plants (first plant, lanes 2, 3, and 5; second plant, lanes 4 and 6 ) were left untreated (lanes 1,2) or incubated with Cfol (lanes 3-6). Blots were hybridized with ACMV DNA A clone pJS092-a DNA A-specific probe (lanes 1-4) - and with pTYE1.2-a probe for the putative TYLCV DNA A and $B$ common region (lanes 5,6 ). The positions of the open circular (Oc) and supercoiled (sc) TYLCV DNA forms are indicated. The sizes (in $\mathrm{kbp}$ ) of the hybridizing fragments and the position of the linear TYLCV dsDNA, are shown.

transformed it into fragments whose length added up to $2.8 \mathrm{kbp}$. Hybridization with the IR probe did not reveal any new bands in addition to those deduced from the restriction map of the cloned TYLCV DNA or already detected by the DNA A-specific probes. For example, when DNA from infected plants was cut by $C f o l$ (see location in Fig. 6), a fragment of $\sim 2.0 \mathrm{kbp}$ was seen upon hybridization of the blot with the DNA Aspecific probe pJS092 (Fig. 7, lanes 3, 4). The same 2.0-kbp fragment and a $0.8-\mathrm{kbp}$ fragment were seen when the blot was hybridized with the IR probe (Fig. 7, lanes 5,6$)$. These two fragments only were detected following hybridization with the DNA A-specific pTYH20.23 probe (not shown). Hybridizations were performed under conditions of both high and low stringency. The only difference between the results was the nonspecific labeling of plant genomic DNA under low stringency hybridization conditions.

\section{The putative TYLCV DNA B was not found in TYLCV ssDNA from infected plants}

We followed the same rationale as in the analysis of viral dsDNA, using an unexpected activity of the restriction endonuclease Aatll. Sequence variation exists at the recognition site for this enzyme in the genome of TYLCV. Although there are no sites for Aatll in the
Hpall clones that were sequenced, in other clones (e.g., pTYE1) a unique Aatll site exists in the IR (Fig. 2, nucleotides 218-223). When total DNA from an infected plant was incubated with Aatll or with $B c / l$, the viral dsDNA was completely linearized to a $2.8-\mathrm{kbp}$ band (Fig. 8A, lanes 3,4). Unexpectedly, in the Aatlltreated sample the viral ssDNA was also completely cut, being replaced by two fragments. We did not anticipate this result, as specificity for SSDNA was not described previously for this enzyme. The two ssDNA fragments produced by treatment with Aatll were detected when blots were hybridized either with the IR probe (Fig. 8B, lane 2) or with the DNA A-specific probes pTYH19.16 and pTYH20.15 (Fig. 8B, lanes 1, 3). Uncut ssDNA could not be detected in the Aatlltreated sample by either probe. The fact that the DNA A-specific probes detect the same ssDNA fragments as the $I R$ probe excludes the possibility that any of these fragments come from a putative $B$ component.

Using the DNA A-specific probes, we delimited the second Aatll restriction site in the ssDNA of TYLCV (Fig. 8B) to the region of 260 nucleotides between these two probes (nucleotides 1902 to 2162 , Figs. 2
A

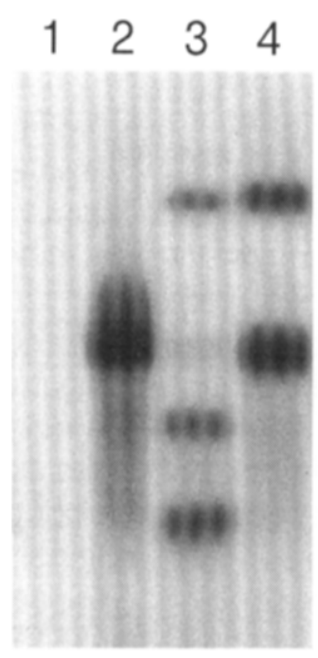

B

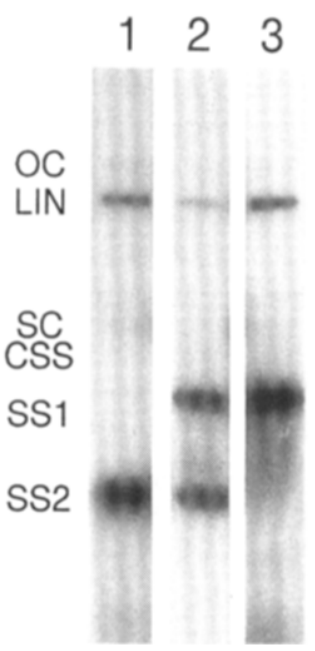

FIG. 8. Restriction and hybridization analyses of TYLCV ssDNA in plants. (A) Effect of Aatll treatment on TYLCV ssDNA. Total nucleic acids from an uninfected tomato plant (lane 1) and from an infected plant (lanes 2-4) were left uncut (lanes 1,2) and were treated with Aatll (lane 3) and with Bc1l (lane 4). Blots were probed with pTYH20.7, a clone with a complete tandem repeat of the TYLCV genome. The positions of the linear (lin), supercoiled (sc), and circular single-stranded (css) DNA forms and the ssDNA fragments (ss 1 and ss2) are indicated. (B) Mapping of the additional Aatll site. Total nucleic acids from an infected tomato plant were treated with Aatll. Blots were hybridized with the DNA A-specific probes pTYH19.16 (lane 1) and PTYH20.15 (lane 3) and with pTYE1.2, a probe for the putative TYLCV common region (lane 2) (probes mapped in Fig. 6). The positions of the oc, lin, sc. css, and cleaved ssDNA forms (ss1 and ss2) are indicated. 
and 6). Three imperfect Aatll sites, each with one mismatch, are found in this region. It is possible that an interaction between sequences spanning the proper Aatll site and sequences around one of the three partial sites resulted in the formation of a double-stranded region; this allowed the enzyme to cut the SSDNA and produce the two observed fragments.

\section{The putative TYLCV DNA B was not found in viruliferous whiteflies}

To discriminate between DNA $A$ and the putative DNA $B$ present in viruliferous whiteflies, we intended to cleave the ssDNA of the $A$ component into several fragments without affecting the $B$ component. If a $B$ component was present, one would expect (following hybridization with the IR probe) to see an uncut DNA species representing the DNA B molecules, in addition to the fragments resulting from the cleavage of DNAA.

On the basis of the sequence of the cloned TYLCV genome, we synthesized three 18-mer oligonucleotides complementary to different regions in the ssDNA genome (Fig. 6). Each oligomer contained a single recognition site for one of the following restriction endonucleases: Apal (from nucleotide 456 to 473), Xbal (from nucleotide 2054 to 2071), and Sacl (from nucleotide 2498 to 2515) (Fig. 2). After annealing the oligomers with a DNA extract from viruliferous whiteflies, the partially dsDNA was incubated with a mixture of Xbal, $S a C l$, and Apal. The DNA was subjected to electrophoresis and blots were hybridized to the DNA A-specific probe pTYH20.23. Three bands were detected (Fig. 9, lane 2) and the circular ssDNA disappeared, as expected from the sequence of the TYLCV DNA A-like genome. When the IR probe was used, only the middle sized band corresponding to the Apal-Sacl fragment of 745 nucleotides (Fig. 6) was seen (Fig. 9, lane 3). Unrestricted SSDNA was not detected by either probe. DNA from nonviruliferous whiteflies before and after incubation with the oligonucleotides did not hybridize with any TYLCV probe. These results showed that the only TYLCV DNA component detectable in viruliferous whiteflies is of the A type.

\section{DISCUSSION}

On the basis of the genome structure of whiteflytransmitted geminiviruses, it was assumed that a bipartite genome would also be found for TYLCV. However, all the clones obtained from the viral RF were from one DNA A-like component.

We demonstrated that this single component has the capacity to cause systemic infection in tomato, coupled with severe yellow leaf curl disease symptoms. Still, by using agroinoculation to produce an insect-transmitted viral disease, one might miss a sec-

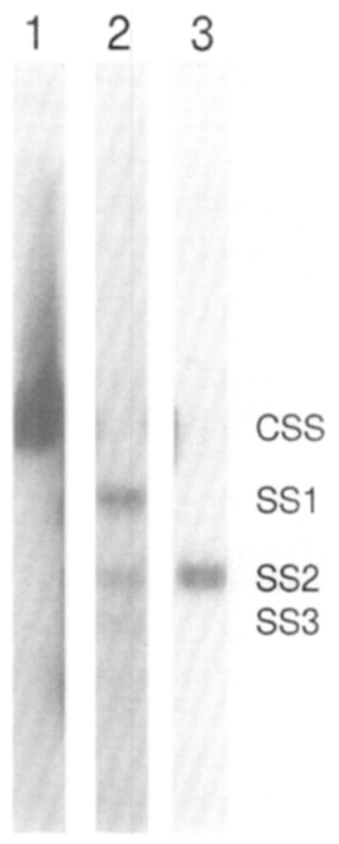

FiG. 9. Restriction and hybridization analyses of TYLCV SSDNA present in viruliferous whiteflies. Total nucleic acids extracted from 200 viruliferous whiteflies were hybridized in solution with three single-stranded 18-mer oligonucleotides, complementary to three regions in DNA A of TYLCV. Each oligonucleotide contained a single restriction site for Apal, Xbal, or Sacl (see Fig. 6). The partially double-stranded DNA was left untreated (lane 1) or was incubated with a mixture of the three enzymes (lane 2). The blot was hybridized with the DNA A-specific probe pTYH20.23 (lanes 1, 2). After autoradiographic exposure, the probe was stripped by boiling in $1 \%$ SDS and $0.1 \times$ SSC, and the blot containing the restricted DNA (lane 3) and the unrestricted DNA (as in lane 1) was rehybridized with the probe for the common region pTYE1.2 (probes described in Fig. 6). The positions of the circular single-stranded (css) and cleaved SSDNA forms (ss 1-3) are indicated.

ond genomic component or a viral function essential for the plant-to-plant transmission of the virus. Therefore we let whiteflies transmit the TYLCV disease from the agroinoculated plants to uninfected test plants. Typical disease symptoms appeared in all test plants, and viral nucleic acids were detected in leaves and roots of these plants. These results proved that the single genomic molecule of TYLCV carries all the information needed for its transmission by insects, replication, and systemic spread.

We initiated the search for the putative B component to exclude the possibility that it is present in TYLCV-infected tomato but is not required at any stage of the virus infection cycle. Results of cloning experiments and of restriction and hybridization analyses of viral DNA forms in infected plants and viruliferous whiteflies could not corroborate the existence of a second genomic component. In TGMV the presence of the B component was necessary for virus movement in the infected plant (Rogers et al., 1986; Sunter et al., 1987). On the other hand, when ACMV DNA A was agroinoc- 
ulated into Nicotiana benthamiana, some systemic spread was observed, but no symptoms appeared (Klinkenberg and Stanley, 1990). DNA A of a TYLCVlike isolate from Thailand seemed even less dependent on DNA B, as it was capable both of systemic movement and of mild symptom production in agroinfected tobacco and tomato plants (Rochester et al., 1990). Recently a TYLCV-like isolate from Sardinia was shown, through molecular analysis, agroinoculation, and whitefly-mediated transmission, to possess a single genomic molecule capable of producing the complete disease cycle (Gronenborn, B., personal communication). It is possible that TYLCV and the Sardinian virus represent a time in the evolution of whitefly-transmitted geminiviruses, prior to the emergence and specialization of a second genomic component, before DNA A became reliant on the second component for systemic infection and production of the full disease symptoms. The absence of a B component in the genomes of these viruses supports the notion that DNA B has no function in the interaction of a whitefly-transmitted geminivirus with its vector (Etessami et al., 1988).

Sequence analysis of the cloned TYLCV genome revealed the presence of a second ORF on the virion strand (designated V2), in addition to the ORF for the coat protein. A highly homologous ORF of $13.1 \mathrm{kDa}$ has been found in ACMV (Townsend et al., 1985) as well as in the TYLCV-like virus from Sardinia (Gronenborn B., personal communication), but not in other whitefly-transmitted geminiviruses. A comparable "precoat" ORF (designated V1 or R2) is present in the genomes of all the leafhopper-transmitted geminiviruses, although the homology it shares with $V_{2}$ of TYLCV is limited (Table 1). Deletion of $V 1$ from the genome of wheat dwarf virus (WDV) had no effect on its ability to replicate in protoplasts of cereals (Laufs et al., 1990; Ugaki et al., 1991). Mutational analysis of this ORF in maize streak virus (MSV) showed that it encodes an essential function (Mullineaux et al., 1988), most probably associated with systemic spread of the virus (Boulton et al., 1989; Lazarowitz et al., 1989). In contrast, its complete deletion in ACMV had no effect on the ability of the mutated DNA A to cause systemic infection, following its introduction, together with DNA $B$, into $N$. benthamiana (Klinkenberg et al., 1989). It might be that $\mathrm{V} 2$ of TYLCV and the $13.1-\mathrm{kDa}$ ORF of ACMV have the same function as $V 1$ of leafhoppertransmitted geminiviruses but are needed for systemic spread only in some of their plant hosts. The loss of this gene in other whitefly-transmitted geminiviruses might have occurred during their evolution, as they or their progenitor virus acquired new hosts for which no such function was needed. Mutational analysis of $\mathrm{V} 2$ in TYLCV and ACMV is expected to assist in determining the function of this ORF.

\section{ACKNOWLEDGMENTS}

Excellent technical assistance was provided by Sara Ovadia and Tzili Pleban. We thank Dr. J. Stanley for probes of ACMV; Drs. Z. Livneh and G. Yagil for helpful discussions; Drs. H. Jeske and B. Gronenborn for sharing with us their results prior to publication and for helpful discussions; Dr. A. Kheyr-Pour for his assistance in agroinoculation experiments; Drs. S. Cohen and $\mathrm{H}$. Antignus for greenhouse TYLCV-infected plants; and the staff of the Center for Micro Computers at the Weizmann Institute of Science for assistance and use of their facilities. This research was supported by BARD Project I-1110-86 and by Yissum.

\section{REFERENCES}

AbouzID, A. M., FrISChMUT, T., and JESKE, H. (1988). A putative replicative form of the abutilon mosaic virus in chromatin-like structure. Mol. Gen. Genet. 212, 252-258.

AN, G., EBert, P. R., MITRA, A., and HA, S. B. (1988). Binary vectors. In "Plant Molecular Biology Manuel" (S. B. Gelvin, R. A. Schilperoort, and D. P. S. Verma, Eds.), Section A3, pp. 1-19. Kluwer Academic Pubs. Dordrecht, The Nederlands.

BeVAN, M. (1984). Binary vectors for plant transformation. Nucleic Acids Res. 12, 8711-8721.

Boulton, M. I., Steinkellner, H., Donson, J., Markham, P. G., King, D. I., and DAVIES, J. W. (1989). Mutational analysis of the virionsense genes of maize streak virus. J. Gen. Virol. 70, 2309-2323.

BREATHNACH, R., and ChAMBON, P. (1981). Organization and expression of eucaryotic split genes coding for proteins. Annu. Rev. Biochem. 50, 349-383.

COHEN, S., and Harpaz, I. (1964). Periodic, rather than continual, acquisition of a new tomato virus by its vector, the tobacco whitefly (Bemisia tabaci Gennadus). Ent. Exp. Appl. 7, 155-166.

Czosnek, H., Ber, R., Antignus, Y., Cohen, S., Navot, N., and Zamir, D. (1988a). Isolation of the tomato yellow leaf curl virus-A geminivirus. Phytopathology 78, 508-512.

CZosnek, H., Ber, R., Antignus, Y., Cohen, S., Navot, N., and ZAMir, $D$. (1988b). Detection of tomato yellow leaf curl virus in lysates of plants and insects by hybridization with a viral DNA probe. Plant Dis. 72, 949-951.

CZosnek, H., Ber, R., NAvot, N., Antignus, Y., Cohen, S., and ZAMir, D. (1989). Tomato yellow leaf curl virus DNA forms in the viral capside, in infected plants and in the insect vector. J. Phytopathol. $125,47-54$.

CZOSNEK, H., NAVOT, N., and LATERROT, H. (1990). Geographical distribution of tomato yellow leaf curl virus: $A$ first survey using a specific DNA probe. Phytopathol. Medit. 29, 1-6.

DAVIES, J. W., and STANLEY, J. (1989). Geminivirus genes and vectors. Trends Genet. 5, 77-81.

DevereuX, J., HaerberL, P., and Smithies, O. (1984). A comprehensive set of sequence analysis programs for the VAX. Nucleic Acids Res. 12, 387-395.

Elmer, J. S., Brand, L., Sunter, G., Gardiner, W. E., Bisaro, D. M., and Rogers, S. G. (1988). Genetic analysis of tomato golden mosaic virus. II. The product of the AL1 coding sequence is required for replication. Nucleic Acids Res. 16, 7043-7060.

Etessami, P., Callis, R., Ellwood, S., and Stanley, J. (1988). Delimitation of essential genes of cassava latent virus DNA 2. Nucleic Acids Res. 16, 7043-7060.

FEINBERG, A. P., and VogeLsTEIN, B. (1984). A technique for radiolabeling DNA restriction endonuclease fragments to high specific activity. Anal. Biochem. 137, 266-269.

GOODMAN, R. M. (1977). Single-stranded DNA genome in a whiteflytransmitted plant virus. Virology 83, 171-179.

Grimsley, N., HOHN, T., DAVIES, J. W., and HOHN, B. (1987). Agrobac- 
terium-mediated delivery of infectious maize streak virus into maize plants. Nature (London) 325, 177-179.

HAMILTON, W. D. O., BISARO, D. M., and BUCK, K. W. (1982). Identification of novel DNA forms in tomato golden mosaic virus infected tissue: Evidence for a two component genome. Nucleic Acids Res. 10, 4901-4912.

Hamilton, W. D. O., Stein, V. E., Coutts, R. H. A., and Buck, K. W. (1984). Complete nucleotide sequence of the infectious cloned DNA components of tomato golden mosaic virus: Potential coding regions and regulatory sequences. $E M B O$ J. 3, 2197-2205.

HOEKEMA, A., HIRSH, P. R., HOOYKAAS, P. J. J., and SCHILPEROORT, R. A. (1983). A binary plant vector strategy based on separation of the vir and T-region of the Agrobacterium tumefaciens Ti-plasmid Nature (London) 303, 179-180.

IKEGAMI, M., HABER, S., and GOODMAN, R. (1981). Isolation and characterization of virus-specific double-stranded DNA from tissues infected by bean golden mosaic virus. Proc. Natl. Acad. Sci. USA 78, 4102-4106.

KLINKENBERG, F. A., ElLWOod, S., and StANLEY, J. (1989). Fate of African cassava mosaic virus coat protein deletion mutants after agroinoculation. J. Gen. Virol. 70, 1837-1844.

KLINKENBERG, F. A., and STANLEY, J. (1990). Encapsidation and spread of African cassava mosaic virus DNA A in the absence of DNA B when agroinoculated to Nicotiana benthamiana. J. Gen. Virol. 71, 1409-1412.

Laufs, J., Wirtz, U., Kammann, M., Matzeit, V., Schaefer, S., SCHELL, J., CZERnilowskr, A. P., BAKer, B., and GRonenborn, B. (1990). Wheat dwarf virus $A c / D$ s vectors: Expression and excision of transposable elements introduced into various cereals by a viral replicon. Proc. Natl. Acad. Sci. USA 87, 7752-7756.

LAZAROWITZ, S. G. (1987). The molecular characterization of geminiviruses. Plant Mol. Biol. Reprod. 4, 177-192.

LAZAROWITZ, S. G., and LAZDINS, I. B. (1991). Infectivity and complete nucleotide sequence of the cloned genomic components of a bipartite squash leaf curl geminivirus with a broad host range phenotype. Virology 180, 58-69.

Lazarowitz, S. G., PInder, A. J., Damsteegt, V. D., and Rogers, S. G. (1989). Maize streak virus genes essential for systemic spread and symptom development. EMBO I. 8, 1023-1032.

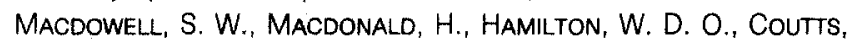
R. H. A., and Buck, K. W. (1985). The nucleotide sequence of cloned wheat dwart virus DNA. EMBO f. 4, 2173-2180.

MAKKOUK, K. M., and LATERROT, H. (1983). Epidemiology and control of tomato yellow leaf curl virus. In "Plant Virus Epidemiology" (R. T. Plumb and Thresh J. M., Eds.), pp. 315-321. Blackwell, Oxford.

MARCK, C. (1988). 'DNA Strider': a 'C' program for the fast analysis of DNA and protein sequences on the Apple Macintosh family of computers. Nucleic Acids Res. 16, 1829-1836.

MAXAM, A. M., and GILBERT, W. (1980). Sequencing end-labelled DNA with base-specific chemical cleavages. In "Methods in Enzymology" (L. Grossman and K. Moldave, Eds.), Vol. 65, pp. 499560. Academic Press, San Diego, CA.

Messing, J., Geraghty, D., Heidecker, G., Hu, N. T., KridL, J., and RUBENSTEIN, I. (1983). Plant gene structure. In "Genetic Engineering of Plants" (T. Kasuge, C. P. Meredith, and A. Hollander, Eds.), pp. 211-227. Plenum, New York.
Mullineaux, P. M., Boulton, M. I., Bowyer, P., Van Der Klugt, R., MARKS, M., Donson, J., and DAVIES, J. W. (1988). Detection of a non-structural protein of $M_{\mathrm{r}} 11,000$ encoded by the virion DNA of maize streak virus. Plant Mol. Biol. 11, 57-66.

NAvot, N., BeR, R., and CZOSNEK, H. (1989). Rapid detection of tomato yellow leaf curl virus in squashes of plant and insect vectors. Phytopathology 79, 562-568.

Rigby, P. W. J., Dieckman, M., Rhodes, C., and Berg, P. (1977). Labelling deoxyribonucleic acid to high specific activity in vitro by nick translation with DNA polymerase 1. J. Mol. Biol. 113, 237-251.

Rochester, D. E., Kositratana, W., and Beachy, R. N. (1990). Systemic movement and symptom production following agroinoculation with a single DNA of tomato yellow leaf curl geminivirus (Thailand). Virology 178, 520-526.

Rogers, S. G., Bisaro, D. M., Horsch, R. B., Fraley, R. T., Hoffman, N. L., Brand, L., ELmer, J. S., and Lloyd, A. M. (1986). Tomato golden mosaic virus $A$ component DNA replicates autonomously in transgenic plants. Cel/ 45, 593-600.

Sambrook, J., Fritsch, E. F., and Maniatis, T. (1989). "Molecular Cloning: A Laboratory Manual." Cold Spring Harbor Laboratory, Cold Spring Harbor, NY.

SAnger, F., Nicklen, S., and Coulson, A. R. (1977). DNA sequencing with chain-terminating inhibitors. Proc. Natl. Acad. Sci. USA 74, 5463-5467

SChalK, H. ., MAtzeit, V., SChiller, B., Schell, .., and Gronenborn, B. (1989). Wheat dwarf virus, a geminivirus of graminaceous plants needs splicing for replication. EMBO J. 8, 359-364.

STANLEY, J. (1983). Infectivity of the cloned geminivirus genome requires sequences from both DNAs. Nature (London) 305, 643645.

STANLEY, J., and GAY, M. R. (1983). Nucleotide sequence of cassava latent virus DNA. Nature (London) 301, 260-262.

Stanley, J., Markham, P. G., Callis, R. J., and Pinner, M. S. (1986). The nucleotide sequence of an infectious clone of the geminivirus beet curly top virus. EMBO J. 8, 1761-1767.

STANLEY, J., and TOWNSEND, R. (1985). Characterization of DNA forms associated with cassava latent virus infection. Nucleic Acids Res. 13, 2189-2206.

Sunter, G., Gardiner, W. E., Rushing, A. E., Rogers, S. G., and BISARO, D. M. (1987). Independent encapsidation of tomato golden mosaic virus $A$ component DNA in transgenic plants. Plant Mol. Biol. 8, 477484.

TAYLOR, B., and POWELL, A. (1982). Isolation of plant RNA and DNA. Focus 4, 4-6.

TOWnsend, R., StAnley, J., Curson, S. J., and SHORT, M. N. (1985). Major polyadenylated transcripts of cassava latent virus and location of the gene encoding coat protein. EMBO s. 4, 33-37.

Ugaki, M., Ueda, T., Timmermans, M. C. P., Vieima; I., Olliston, K. O., and MESSING, J. (1991). Replication of a geminivirus derived shuttle vector in maize endosperm cells. Nucleic Acids Res. 19, $371-377$

ZEIDAN. M., and CZOSNEK, H. (1991). Acquisition of tomato yellow leat curl virus by the whitefly Bemisia tabaci. J. Gen. Virol., in press.

Zilberstein, A., Navot, N., Ovadia, S., Reinhartz, A., HerzBerg, M., and CZOSNeK, H. (1989). Field-usable assay for diagnosis of the tomato yellow leaf curl virus in squashes of plants and insects by hybridization with a chromogenic DNA probe. Technique 1, 118124 